\title{
Heterogenity of Amber and Komin in Shaping Settlement Pattern of Jayapura City
}

\author{
Alfini Baharuddin ${ }^{1}$, B. Hari Wibisono ${ }^{2}$, Budi Prayitno ${ }^{2}$, M. Sani Roychansyah ${ }^{2}$ \\ ${ }^{1}$ Department of Architecture Universitas Sains dan Teknologi Jayapura \\ ${ }^{2}$ Department of Architecture and Planning, Gadjah Mada University
}

Permalink/DOI: http://dx.doi.org/10.15294/komunitas.v7i2.3287

Received : August 2015; Accepted: September 2015; Published: September 2015

\begin{abstract}
Jayapura city is the capital of Papua province, located at the eastern end of Indonesia and meet the border with neighboring country, Papua New Guinea. From the results of population census in 2010 the population, Jayapura has 256.705 inhabitants with a number of indigenous people as many as 89.773 people (34.97\%) and 166.932 non-Papuan population (65.03\%). This figure shows that in Jayapura, the number of migrants exceeds the number of indigenous people. The terms Amber and Komin then appear, referring to the indigenous people of Papua (Komin) and non-Papuan migrants (Amber). The high migration flows in Jayapura results in the diversity of socio-cultural and economic structures within the population and impacts on the formation of population settlement patterns. This paper discusses the ethnic heterogeneity of community in Jayapura in shaping the settlement patterns. From the discussion, it is known that the existing settlements in Jayapura city consists of settlement inhabited by indigenous peoples, settlement inhabited by mixed population of Papuan and nonPapuan population, settlement inhabited by Papuan ethnics from outside the city of Jayapura and settlements inhabited by ethnic immigrants of non-Papuan. The settlement of indigenous people still survives as customary settlement which upholds and maintain conserve the spiritual and religious meaning. And the settlement of Papuan and non-Papuan migrants are established based on several preferences, namely the bonds of kinship, proximity to sources of livelihood (workplace), and social status.
\end{abstract}

Keywords: heterogeneity, Amber and Komin, settlement patterns, Jayapura

\section{INTRODUCTION}

Jayapura is the capital city of Papua province, located at the eastern end of Indonesia and met with the border of neighboring country, Papua New Guinea. Jayapura covers the area of $940 \mathrm{~km}^{2}$ with the $30 \%$ of the total area is an area that cannot be developed because it has a slope of more than $40 \%$. The geographical conditions in Jayapura are dominated by hills, causing the formation of city patterns which is scattered in parts of the area that can be inhabited and developed. Even with the increasing number of people, there are also resident settlements that should not be built, such as the one on the slopes of steep hills. Hartshorn (1992) suggests that the settlement function is the largest part of the land use of a city.

This paper discusses the ethnic heterogeneity of community in Jayapura in shaping the settlement patterns. Current studies on urban settlement rarely pay attention to the heterogeneity of the community as a factor in shaping settlement (Brown and Robinson 2006; Jones and Suhartini 2014; Numbasa and Koczberski 2012). This paper is also important because it explores the heterogeneity and settlement in Jayapura.

Jayapura population growth is more influenced by aspects of migration rather than natural cause. Significant migration has been taking a significant effect on po- (c) 2015 Semarang State University. All rights reserved p-ISSN 2086 - 5465 | e-ISSN 2460-7320 
pulation growth in Jayapura since 1963 when Irian Jaya became part of the Homeland. Earlier, during the reign of the Dutch East Indies, residents from outside the city of Jayapura were strictly limited and filtered so that the needs of the population could be met in accordance with the available facilities and infrastructures. Garnaut and Manning (1979) classify the coming of migrants to Irian Jaya into three groups, the first is the group of state officers and experts as well as big corporations employees that entered Irian Jaya to fill in the available positions; second group consists of farmers who were brought from Java to settle in Irian Jaya for government transmigration program; and third, migrants who moved at their own expense and expectd to get a job after arriving in Irian Jaya (Ammarell 2002; Numbasa 2012).

The migrants in Jayapura came from several tribes outside Papuan (Bugis, Makassar, Buton, Javanese, etc.) and Papuan tribes outside the city of Jayapura (Biak, Serui, Sorong, Wamena, etc.). Migrants from outside Papua who get into Jayapura are more dominant than the population outside the city of Jayapura, resulting in a high population growth rate (Muhidin 2014). From the results of population census in 2010 (Figure 1), the population of Jayapura is 256.705 people with a number of indigenous people as many as 89.773 Papuan people
(34.97\%) and 166.932 of non-Papuan people $(65.03 \%)$. This figure shows that in Jayapura, the number of non-Papuan migrants is far more than native Papuans. This picture is seen in all districts in the city of Jayapura.

The categories of Papuan and non-Papuan populations have become a discourse within socio-cultural layers of the population in Jayapura and raised political dynamics (Jones and Suhartini 2014). Papuan has emerged as an identity among the first generation of people in Biak, Serui, and others who were educated by Dutch. The identity of the board was strengthened as a result of interaction between indigenous Papuans with the employees of colonial settlers. During its development, the term Papuan was opposed to the Amber which is the term for 'comers'. According Chauvel, Papuan identity was born as part of the expression of rivalry and antagonism of the Papuan indigenous people versus Amber as well as an early form of Papuan solidarity. The establishment of pan-Papuan identity and historical perspective on this amber stems from a system of 'dual colonialism' of Dutch. In the elite and senior positions of colonial administration and missionary organizations, there were Dutch people. The middle and lower positions were occupied by employees of Amber. In everyday life, the representation of the colonial government was this $\mathrm{Am}$ ber. Contestation atmosphere and growing

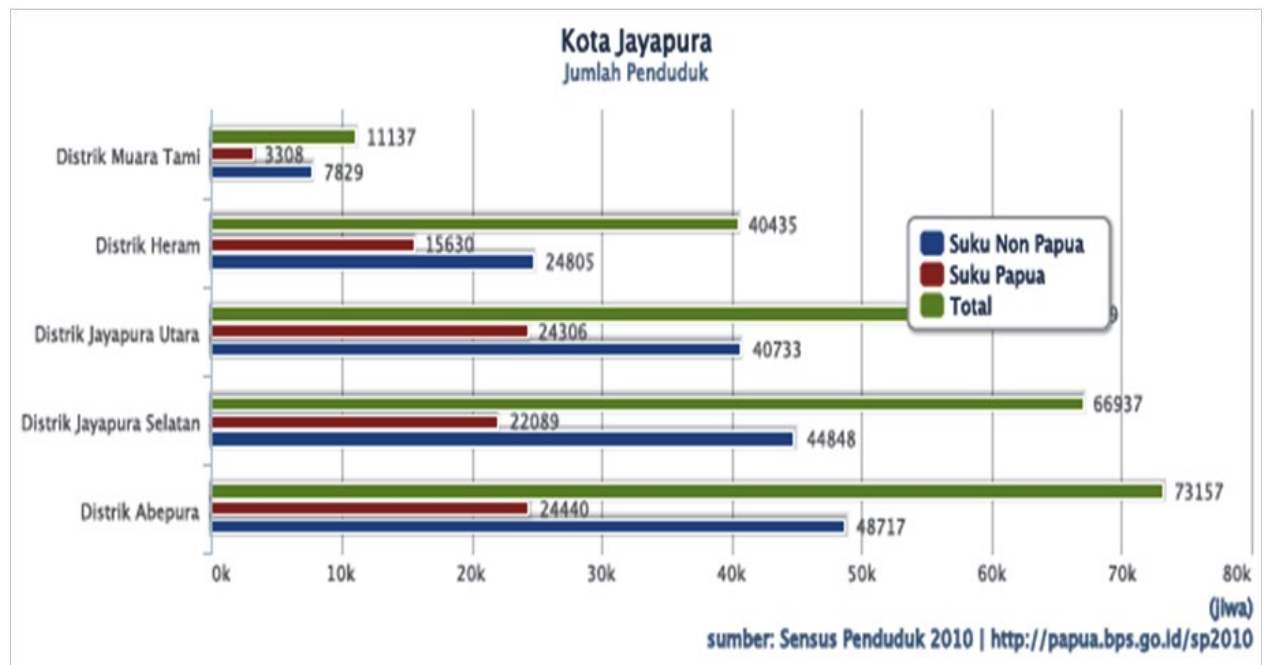

Figure 1. The Graph of Jayapura Population per district (Papuan and non-Papuan) Source: BPS Papua Province, 2010 
antagonism between the indigenous Papuan with Amber was more focused on the Amber who were considered as 'lackeys of colonials' rather than the Dutch themselves who were not in daily contact with the people of $\mathrm{Pa}-$ pua. Indigenous Papuans saw the amber as strangers who colonized their land. The subjective view was not separated from the bias interests of the Dutch colonial government who wanted to maintain Papua at the time. After 1945, Papuans began to be educated as an employee and recruitment was done massively. The Amber-Papuan relationship was constructed by the colonial literature in antagonistic character. Meanwhile, the Dutch was constructed as protagonists and noble to be the carrier of education advancement, Christianity, prosperity and humane treatment for indigenous Papuans. Since 1963, when the Republic of Indonesia came to rule in Papua, the opposition was stronger and increasingly becomes the engine for Papuan nationalism. Amber was identified with Indonesia's attendance as the new colonizers. (Widjojo et al. 2009).

In everyday social life, physically distinguishing Amber and Komin is very easy. Amber is a term that is intended for migrants with straight hair, while Komin is addressed for the Papuans with curly hair. Economic gap between migrants and Papuan population often causes social problem that leads to the hindrance in the interaction between Amber and Komin. Kinasih (2013) states that social interaction is a social process that includes cooperation, competition, and even conflict. Prejudice and stereotype play as triggering factors for such conflict. Lekitoo (2003) reveals how Papuans are marginalized in their own land, especially in terms of entrepreneurship. One of the internal social barriers for Papuans in entrepreneurship, among others, is the bond of kinship. Kinship for Papuans means that they must help each other if anyone needs help, regardless of whether there are people being disadvantaged because of the unbalanced relationship. This becomes an obstacle for Papuans to do business and they must sacrifice their business because they put priority for their relatives. Besides the problem of kinship, ot- her causes of low desire of the Papuans to do entrepreneurship is because of "shame" culture for entrepreneurship, for example, to be a street vendor. Entrepreneurial job is considered shameful because it is only done by migrants who are considered not having anything. Papuans themselves feel they have a vast land, rich natural resources, and relatives who are ready to help when they are in trouble. The next cause is the fast-paced and want-to-be served mentality. This attitude may be influenced by the tradition of Papuans where they get all they want from their surroundings. Without the need to work hard, nature has provided the necessities of their life.

In line with Lekitoo, Akhmad (2005) explains the economic changes in Papua by viewing the economic change occurred in migrants from Bugis (Amber) and economic change of Papuans (Komin). Papuans lag in terms of the market economy is due to internal factors. The nature of their economy is based on barter system which is also related to other social elements such as kinship, prestige, religion and leadership. The market economy which is done by people of Papua is related to subsistence economy where subsistence production such as fish, vegetables, sago and others, are traded only if they do not consume it by themselves. The situation raises impersonal behavior with the advent of anti-social attitudes, ignoring the system of subscription and bargain because they feel nothing to lose if they do not sell goods as they can be consumed at home. The formation of impersonal behavior causes Papuan traders have not been fully integrated in a market society that emphasizes personal relationships. Conversely, the success factors of Bugis migrants in a market economy is by harnessing economic opportunities accurately and efficiently, utilizing social networks such as family and intra-ethnic and inter-ethnic. Such bonds are used as tools to strengthen their position as a trader, beside trying to maintain personal contact with buyers and distributors of goods.

In the Act No. 21 of 2001 on Special Autonomy, Papuan societies are deliberate- 
ly planned and sub-divided or categorized into several groups. The division of society according to autonomy formally consists of indigenous peoples, community of customary law, indigenous Papuans and population of the Papua province. The division of society which is officially implemented by the state has brought some consequences, such as the separation of the population based on socio-politics, social, cultural, regional, biological, heredity, race, ethnicity and customs. In addition to the socio-political structure of the official creation of the state, it is also found that the social structure of the population has formed its own unique community because of sub-divided or categorized population based on various specific characteristics. Plural society which is multi-racial, multi-ethnic (tribal), multicultural, multi-religious, multi-language undergoes the process of structuring a deliberate formation (formal) through organic processes (Lapona 2008).

The existence of a growing population and a growing ethnic heterogeneity in Jayapura impacts on the emergence of new settlements that form the spatial pattern of Jayapura. Some settlements which have existed since the Dutch colonial government are now inhabited by people from various cultural backgrounds and social classes. Some settlements which were formerly inhabited by certain ethnic such as Kampung China, Kampung Ambon and Kampung Key are now inhabited by various ethnic groups. The settlements for the Dutch elites, namely Noordwijk and Hemelsport now known as Dok V Atas and Angkasapura, until today are still known as the elite settlement for the upper middle class. But behind the development of settlements, Jayapura native settlements as a traditional village are maintained.

\section{RESEARCH METHODS}

This research was a qualitative descriptive study. The collected data consisted of primary data and secondary data. The primary data was obtained through direct observation, while secondary data was obtained from literature sources and related institutions.
The observation was directly conducted to determine the spatial distribution that was formed peculiarities of the settlements in Jayapura. Direct observation was documented, then abstracted into maps in the form of area to illustrate the distribution of settlements in Jayapura.

\section{RESULTS AND DISCUSSION}

Immigrants in Jayapura consist of various ethnic groups all over Indonesia. It can be said that the population of Jayapura shows a great diversity and good views of the area of origin, culture, employment, education, and religion. Mansoben (1999) argues that various cultural backgrounds seem not to be separated from the bonds of kinship and family groups respectively. Kinship and family organizations still have important roles in controlling and influencing the behavior and actions of its members. The organizations serve to monitor cultural behavior of its members and help them in urgent situations (Mansoben 1999). In the city of Jayapura, there are various organizations such as kinship or The Association of Batak Family, The Association of Toraja Family, Family Harmony of South Sulawesi (KKSS), Family Harmony of Southeast Sulawesi (KKST), and so on.

The natives in Jayapura are the tribes of Kayu Batu, Kayu Pulo, Tobati, Engros, and Nafri. Jayapura native settlements are generally located on the water in a form of staged houses. The main livelihood of the natives is fishing. They live in villages that are spread in the Humboldt Bay (now Teluk Yos Sudarso). Until now, the villages of native indigenous Jayapura still survive as customary villages in the midst of rapid flow of migrants and development of Jayapura. The city of Jayapura which is developed in inland areas was formerly the Farms and sago forests belonged to the indigenous population. But today, most of their customary land has been turned into the town and owned by immigrants. However, although most of the tribes of communal land in the city of Jayapura have turned into the city, but their original villages remain exclusive. Until now, the accessibility to the village 
can only be reached by boat because they are still keeping their village as a traditional settlement. In this regard, Seserai (2012) states one example in Kampung Kayu Pulo located on the island in the Gulf of Humbolt where it has built a floating bridge that connects the city to the islands, but bridges are built not fully connect the mainland city of Jayapura; it is only until in the middle of the sea and in order to reach the village on the island, they have to use boats. Villagers do not want the bridge to connect their village for reasons of security and comfort because they think that if the bridge directly connecting the mainland city of Jayapura, they will lose the sense of security because their villages will be easily accessible by people who are not residents of the village.

From the above cases, the side of the mainland of Jayapura which used to be a sago forests and hunt areas can be sold or released to immigrants and employers through the procedure of customary law. And on the other hand, the villages of their native which is very close to the mainland Jayapura city remains protected from the entry of outsiders, despite the opportunities that can facilitate their access to activity centers in the city. This probably reflects the differences in the meaning of land among indigenous peoples. The area which is used for economic advantages and business can be released while the area which has spiritual/religious meaning should be preserved and protected. The empirical case can be seen in Kampung Kayu Pulo, for example, which is protecting the cultural significance of their village. This vision seems to be more prioritized than the provision of infrastructures for villagers to access the various facilities in urban areas. In various reviews of settlement study, accessibility is the most important determinant of a person in preference to settle (Ayodiya 2014). Erari (1999) suggests that there are four social functions for residential areas or villages in Papua, namely:

a. A village is culturally a shelter from the enemies and animals.

b. The village is a source of livelihood.

c. In a village that would be born descendants (house together).

$\mathrm{d}$. The village is the site of family ties, including religious center (church).

During the occupation of the Dutch, settlements of migrants were named according to predecessors who occupied the settlement. Some of them are China Village, Ambon Village and Key Village in Hollandia Binnen (Abepura now). In the China Village, at that time there were a lot of houses and shops which were generally owned by the Chinese. Similarly, Key camp which was formerly occupied by the Key tribe of Southeast Maluku had been there during the reign of the Netherlands. Both of these tribes are the tribes that have long been coming to this area. The Chinese entered the
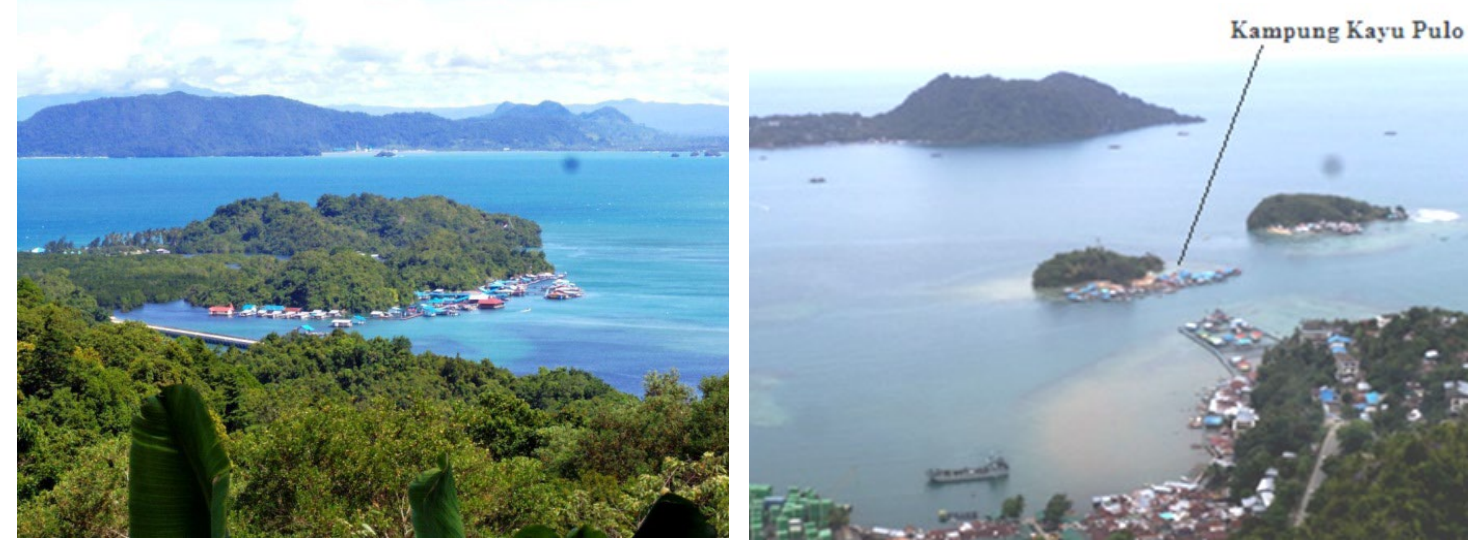

Figure 2. Native settlements of Jayapura: Kampong Kayu Pulo (left) and Kampung Tobati (right)

Source: Authors' Documentation, 2011 
Hollandia to find the bird of paradise, while the people of Maluku, including the Key tribes entered Hollandia in order to spread Christianity and Catholicism. Chinese camp or now called Kotabaru Village is currently inhabited by Papuan people and migrants. There are still citizens of Chinese descents but not many. And Key Camp now belongs to Awiyo Village. Currently, the Key Camp population is composed of various ethnicities.

In addition to China Village and Key Village that have existed since the time of Dutch reign, since the swift flow of migrants to Jayapura, there are also some names of settlements in accordance with tribal inhabitants. They built settlements in urban areas and villages which are concentrated. Lapona (2008) suggests that the grouping of settlements like this happens because of the family relationship, ethnic and friends to get a job. The emergence of ethnic settlement is a form of adaptation strategies developed by migrants in overcoming the obstacles they face to obtain a positive balance with the background conditions of migrants. Some ethnic settlements which are formed in Jayapura include Buton in Skyline Village, Enrekang Village in Nafri, and Wamena Village namely settlement Papuans from the Central Mountains located in the slopes of the hills in Angkasapura. In addition to the settlements that grow based on ethnicities, there are settlements which are formed by the transmigration program inhabited by migrants from Java. This transmigration settlement is in East Koya and West Koya.

Besides the settlements which are formed based on ethnicity in Jayapura, there are settlements which are built based on the differences ability to realize economic and social prestige among the areas of settlement. The settlement is an indication of the social structure in the city of Jayapura. For example, low-income dense residential zone is in the area of Kloofkamp and APO located close to the city center. This area is generally a rental houses inhabited by immigrants who work as a clerk in the government and private companies in the city center as well as informal workers such as street vendors who trade around the downtown area. There is also a secondary residential zone such as the area of Dok V to Angkasapura. This area since the Dutch era has indeed been reserved for the elite Dutch officials who formerly known as Noordwijk, while settlements for employees Papuans lower middle class are in Polimak.

Some ethnics in the city of Jayapura have mastered several types of jobs. Ethnic Bugis and Makassar are the majority of traders in traditional markets. Large-scale trade such as shops and distributors of goods are generally controlled by traders of Chinese descents. Chinese traders have long been in existence since the Dutch colonial period. This is indicated by the settlement of China
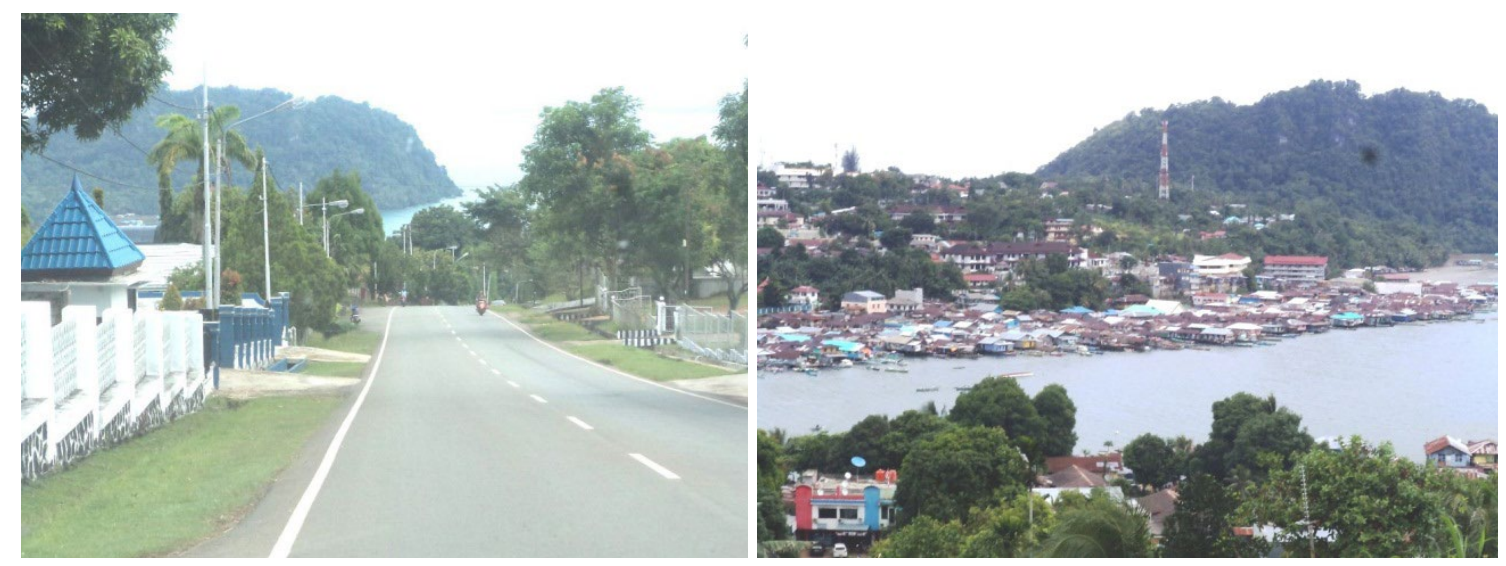

Figure 3. Settlement of fishermen on the docks IX (left) and upper-middle class neighborhood in Dok V inhabited by the ethnic mix (right)

Source: Documentation writer, 2011 


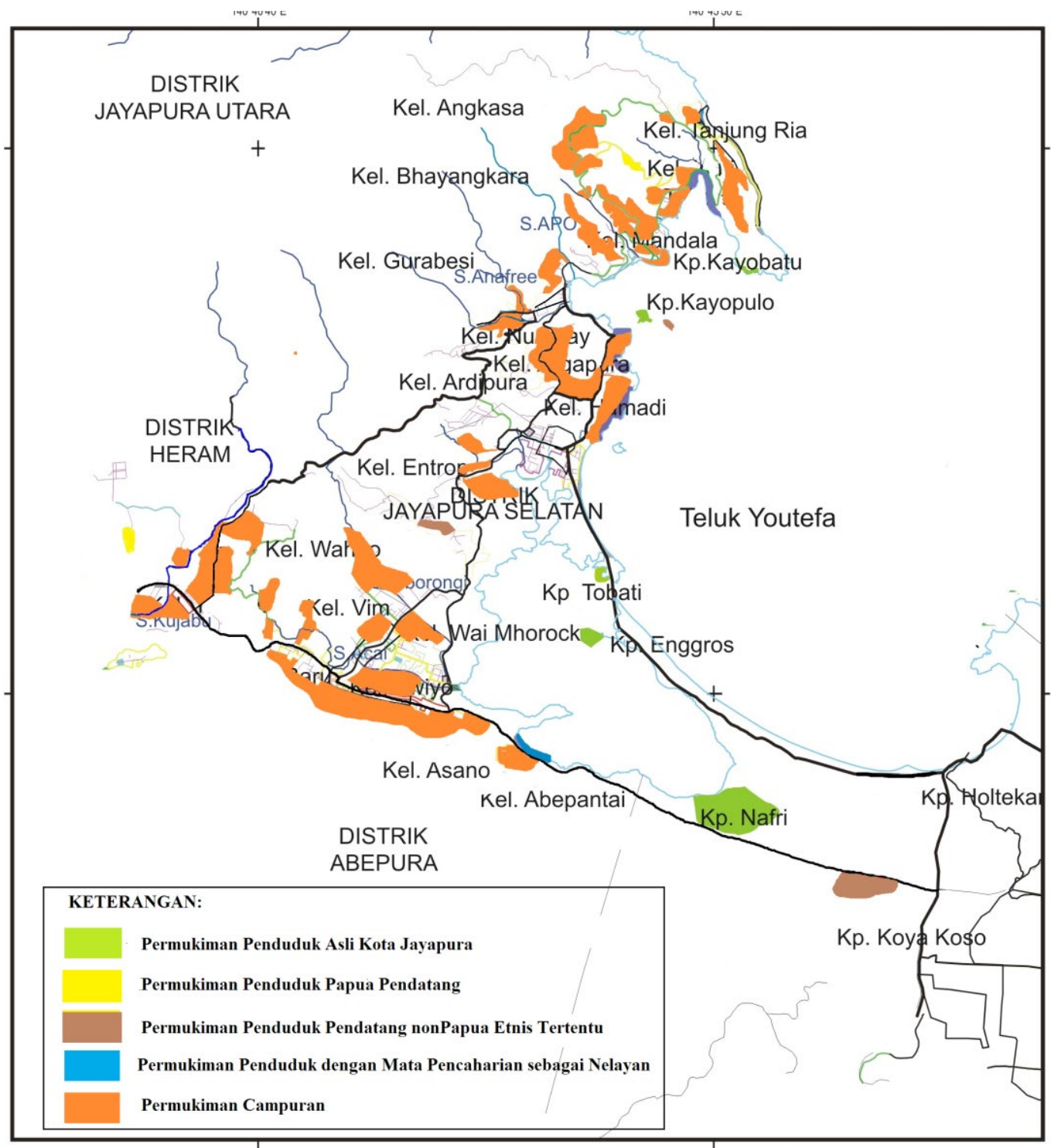

Figure 4. Distribution of settlements that form the spatial pattern of Jayapura City Source: Analysis 2012

Village located in the Abepura or Hollandia Binnen at that time. Papuans themselves are generally small-scale traders who sell betel nuts, vegetables, or fish.

Jayapura City residents are fishermen living on the coast. Papuans who work as fishermen are from local ethnic communities (Kayu Pulo, Kayu Batu, Tobati, Enggros, Nafri), Biak, Seruim, and Sorong. And nonPapuan fishermen are from ethnic Buton, Bugis and Makassar known as BBM. Local ethnic fishermen communities live in their traditional villages. The fishermen Papuans who come from ethnic Biak, Serui, and Sorong generally stay mingling with fisher- men from ethnic Buton, Bugis and Makassar. Their settlements are located on the coast Dok IX, Hamadi, Argapura and Abe Beach.Jayapura residents who are generally working as farmers are Papuans from Central Mountains such as Wamena and Paniai. They built villages and farms by opening the farmland on the slopes of hills or highlands. Their villages among others are in Angkasapura, Waena and Tanah Hitam. In addition to farmers who are Papuans, there are also some ethnic immigrants who are farmers like the homesteader in West Koya and East Koya as well as Enrekang part in Nafri.

Jayapura City residents who are living 
as civil servants, private employees, selfemployed, consist of indigenous Papuans and migrants from various regions such as Java, South Sulawesi, North Sulawesi, Maluku, North Maluku, Sumatra, Bali and NTT. People who work as civil servants and private employees or self-employees live in various settlements in Jayapura. There are also some residential complexes of Local Government (LG) such as in Entrop, Kotaraja and Angkasapura. Housing for Police members are in Kloofkamp, Kotaraja, Angkasapura, and Tanjung Ria. Similarly, housing for members of the military are in Kloofkamp Paldam, Doc V, Bhayangkar a, Kotaraja, Entrop, and Angkasapura. In the settlements, assimilation is generally occurred among various ethnics either from $\mathrm{Am}$ ber or Komin. The settlements are inhabited by various ethnic mix of Amber and Komin are dominant settlements in Jayapura.

\section{CONCLUSION}

Jayapura population consists of a multiethnic in which the population of the city is strongly influenced by the migration of people from out of town. Because of this, in Jayapura, there are terms of Amber which is intended for the migrants and Komin which is intended for indigenous people.

The existence of various ethnic immigrants in Jayapura affects their social and cultural life shown by the strong kinship bonds and adjacent living with relatives from the same tribes. There are settlements inhabited by migrants fr om certain ethnic. Besides settlements inhabited by immigrants, Jayapura native settlements are inhabited by the tribe of Tobati, Enggros, Kayu Pulo, Kayu Batu, and Nafri. Until today, they still preserve their traditional settlements in the middle of the development of Jayapura. Patterns of living in the city of Jayapura are also shown on the types of livelihood. Classification livelihood in Jayapura city can be broadly grouped into the population which is employed by people working in agriculture, fisheries, trade and civil/private sectors. In addition, there are also settlements which are established based on the social status of its inhabitants, such as the upper middle class settlement in Angkasapura, and the lower-middle settlement in Kloofkamp and APO.

From the discussion, it is known that the settlements in the city of Jayapura consist of settlements of indigenous peoples, mix settlements inhabited by Papuans and non-Papuan migrants, settlements inhabited by ethnic Papuans from outside Jayapura (such as Kampung Wamena), and settlements of non-Papua inhabited by migrant ethnics (such as Kampung Buton and Kampung Enrekang). The settlements of indigenous peoples still survive as indigenous settlements that have spiritual/religious meaning that must be maintained and protected. And the settlements that are inhabited by people from outside Jayapura are formed by diverse backgrounds based on kinship, proximity to the source of livelihood (work) and social status.

\section{REFERENCES}

Akhmad. 2005. Studi Perubahan Ekonomi di Papua. Bigraf Publishing, Yogyakarta.

Ammarell, G., 2002. Bugis Migration and Modes of Adaptation to Local Situstions. Ethnology, pp.51-67.

Ayodia, N.R.P., 2014. Model Kebijakan Permukiman Kampung Code Utara di Tepi Sungai Code. Jurnal Pembangunan Wilayah dan Kota, 10(1), pp.22-32.

Basundoro, P., 2012. Penduduk dan Hubungan Antaretnis di Kota Surabaya Pada Masa Kolonial. Paramita, 22(1), pp.1-13.

Brown, D.G. and Robinson, D.T., 2006. Effects of Heterogeneity in Residential Preferences on An Agent-Based Model of Urban Sprawl. Ecology and society, 11(1), pp.46.

Erari, K.P., 1999. Tanah Kita, Hidup Kita : Hubungan Manusia dan Tanah di Irian Jaya Sebagai Persoalan Teologis, Pustaka Sinar Harapan, Jakarta.

Galis, K.W. and Doornik, H.J., 1960. 50 Jaar Hollandia van 7 Maart 1910 tot 7 Mart 196o. Hollandia.

Garnaut, R. and Manning, C., 1979. Perubahan Sosial Ekonomi di Irian Jaya: Integrasi ke dalam Kawasan Indonesia dan Pembangunan Ekonomi. Gramedia, Jakarta.

Harinto, et al. 1986. Perkampungan di Perkotaan Sebagai Wujud Proses Adaptasi Sosial Daerah Irian Jaya, Depdikbud, Jakarta.

Hartshorn, T.A., 1992. Interpreting The City: An Urban Geography. John Wiley \& Sons, Toronto.

Hasanuddin and Kristanto, B.. 2001. Proses Terbentuknya Heterogenitas Etnis di Pontianak pada Abad ke-19. Humaniora, 13(1), pp.64-81. 
Jones, P.R. and Suhartini, N., 2014. Reframing Approaches to Conceptualising Urban Governance in Melanisia: Insights from Jayapura and Port Moresby. Journal of Regional and City Planning, 25(2), pp.96-114.

Kinasih, D., 2013. Interaksi Masyarakat Keturunan Arab dengan Masyarakat Setempat di Pekalongan. Komunitas, 5(1), pp.38-52

Koentjaraningrat and Bachtiar, H.W., 1963. Penduduk Irian Barat. Penerbitan Universitas, Jakarta.

Koentjaraningrat, et al. 1994. Irian Jaya: Membangun Masyarakat Majemuk, Djambatan, Jakarta.

Prabowo, H., 2002. Aplikasi Sistem Informasi Geografi pada Perubahan Sosial dan Spasial Kampung Kota Jakarta (Studi Kasus pada kampung Pasar Minggu, Jakarta Selatan). Prosiding Komputer dan Sistem Inteligen, Universitas Gunadarma, Jakarta.

Prabowo, H. and Suparman, A., 2005. Masalah Etnisitas dan Tata Ruang di Indonesia.

Lapona. 2008. Penduduk dan Politik di Papua. Rewamboina, Jayapura.

Laporan Jurnalistik Kompas. 20o8. Ekspedisi Tanah Papua: Terasing di Negeri Sendiri. Penerbit Buku Kompas, Jakarta.
Lekitoo, H.Y., 2003. Kitorang Tra Maju-Maju: Marginalisasi Orang Papua di Kampung Sendiri. Postgraduate Thesis. Program Pascasarjana Antropologi UGM.

Mansoben, J.R., 1997. Perkembangan Kota Jayapura dan Pengaruhnya Terhadap Sosial Budaya Penduduk Kota Jayapura, Kumpulan Makalah Seminar Hari Ulang Tahun Kota Jayapura.

Menno, S. and Mustamin, A., 1992. Antropologi Perkotaan. Raja Grafindo Persada, Jakarta.

Muhidin, S., 2014. 13 Migration patterns: people on the move. Regional dynamics in a decentralized Indonesia, 501, pp.317.

Numbasa, G. and Koczberski, G., 2012. Migration, informal urban settlements and non-market land transactions: a case study of Wewak, East Sepik Province, Papua New Guinea. Australian Geographer, 43(2), pp.143-161.

Seseray, O.B., 2012. Karakteristik Spesifik Wilayah Kota Jayapura dalam Perencanaan Pembangunan Daerah, Postgraduate Thesis. Program Pascasarjana Universitas Gadjah Mada Yogyakarta.

Widjojo, M. S., et al. 2009. Papua Road Map. LIPI, Yayasan Tifa, Yayasan Obor Indonesia, Jakarta. 